\title{
EXPERIENCE OF THE APPIICATION OF EXISTING EU DIRECTIVES AT THE DEEERMINATION OF THE HAZARD CLASS OF THE INDUSTRIAL WASTE
}

\section{Stankevych V.V., Kostenko A.I., Trakhtengerz G.A. \\ ДОСВІД ЗАСТОСУВАННЯ ВИМОГ ДИРЕКТИВ ЕС ДЛЯ ВИЗНАЧЕННЯ СТУПЕНЯ НЕБЕЗПЕКИ ПРОМИСЛОВИХ ВІДХОДІВ}

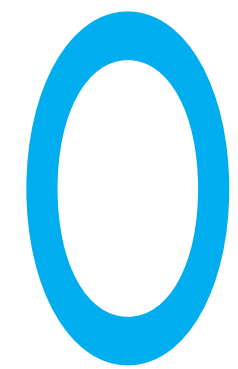

СТАНКЕВИЧ В.В. , КОСТЕНКО А.I., ТРАХТЕНГЕРЦ Г.А.

ДУ «Інститут громадського здоров'я

ім. О.М. Марзєєва НАМН України», м. Київ

УДК

614.78/79:628.4.032

$$
\begin{array}{r}
\text { Ключові слова: } \\
\text { промислові } \\
\text { відходи, } \\
\text { токсичність, } \\
\text { клас небезпеки, } \\
\text { ризики. }
\end{array}
$$

сновною метою усіх положень щодо поводження 3 відходами має бути захист здоров'я людини і довкілля від шкідливого впливу, спричиненого їх збиранням, перевезенням, обробкою, зберіганням та видаленням. Досягнення цієї мети базується на встановленні ступеня небезпеки класу небезпеки відходів для навколишнього середовища і здоров'я населення. Аналіз результатів багаторічних досліджень відходів, що виконуються лабораторією, свідчать, що вагомим критерієм оцінки ступеня небезпеки відходу є комплексний підхід з урахуванням фізико-хімічних властивостей відходу та токсичних характеристик його складових. За цими критеріями проводилися розрахунки індексів токсичності основних токсичних компонентів, за сумарними значеннями яких з урахуванням механізму патогенетичної дії хімічних речовин визначалася потенційна небезпека відходів - встановлення класу небезпеки для довкілля і здоров'я населення, яке проводилося за методикою, викладеною у ДСанПіН 2.2.7.029-99, наразі скасованій [1].

Водночас дослідження різних видів промислових відходів показа- ли, що супутні чинники потенційної небезпеки відходів для довкілля та здоров'я людини у багатьох випадках потребують специфічних підходів та умов щодо поводження. Надзвичайно висока потреба у застосуванні таких підходів була виявлена у тих випадках, коли токсичність суміші складових відходу як така була невисокою. Певний внесок у визначенні небезпеки відходів було здійснено за рахунок речовин, які не враховувалися при обчисленні коефіцієнтів токсичності, але спричиняли негативний антропогенний вплив на оточуюче середовище, змінюючи його параметри та впливаючи на здоров'я людини [2].

Застосування біологічних і радіологічних критеріїв оцінки промислових відходів забезпечило повноту визначення їхньої загальної санітарно-епідеміологічної небезпеки для довкілля та здоров'я людини. Додаткова оцінка складних хімічних утворень промислових відходів з урахуванням супутніх факторів небезпеки (за біологічними та радіологічними ознаками) при визначенні класу небезпеки
ОПЫТ ПРИМЕНЕНИЯ ДЕЙСТВУЮЩИХ ДИРЕКТИВ ЕС ПРИ ОПРЕДЕЛЕНИИ КЛАССА ОПАСНОСТИ ПРОМЫШЛЕННЫХ ОТХОДОВ Станкевич В.В., Костенко А.И., Трахтенгерц Г.А. ГУ «Институт общественного здоровья им. А.Н. Марзеева НАМН Украины», Г. Киев

Цель - обоснование внедрения современных подходов и методик по Директивам ЕС для определения потенциальной опасности отходов. Материалы и методы. Проанализированы подходы к определению класса опасности промышленных отходов; проведено сравнение результатов исследований, получаемых при определении класса опасности с использованием отмененных национальных нормативов, директив и регламентов Европейского Союза. Результаты. Установлено, что использование директив и регламентов Европейского Союза позволяет существенно усовершенствовать методику определения класса опасности промышленных отходов. Такой подход способствует более точному определению потенциальной опасности отходов для здоровья человека, учитывая большее количество факторов и путей воздействия на человеческий организм токсичных, радиоактивных и биологически опасных компо- нентов промышленных отходов по сравнению с методиками, которые использовались в отмененных национальных нормативных документах. Выводы. Определение категории потенциальной опасности смесей компонентов отходов по оценке ингаляционной острой токсичности (OT) позволило определить класс опасности отходов не только по оральной токсичности, но и с учетом ингаляционного пути поступления в организм.

Оценка агрегатного состояния отходов позволила по физико-химическим характеристикам определить категории рисков и безопасности при обращении с ними, что дает возможность обоснованно оценить все возможные проявления потенциальной опасности отходов для окружающей среды и здоровья населения. Реализация системного подхода к определению потенциальной опасности промышленных отходов с применением методик нормативных документов ЕС в целом направлено на усовершенствование регулированного обращения с отходами и улучшения состояния окружающей среды и здоровья населения.

Ключевые слова: промышленные отходы, токсичность, класс опасности, риски. 
EXPERIENCE OF THE APPLICATION OF EXISTING EU DIRECTIVES AT THE DETERMINATION OF THE HAZARD CLASS OF THE INDUSTRIAL WASTE

Stankevych V.V., Kostenko A. I., Trakhtengerz G.A. SI «O.M. Marzeyev Institute for Public Health, NAMSU», Kyiv

Objective: We substantiated the implementation of modern approaches and techniques on the EU Directives for the determination of the potential hazard of waste.

Materials and methods: We analyzed the approaches to the determination of the industrial waste hazard class, carried out a comparison of the results of the studies obtained at the determination of the hazard class using cancelled national standards, directives and regulations of the European Union.

Results: The use of directives and regulations of the European Union makes it possible to improve significantly the methodology for the determination of hazard class of the industrial waste. This approach contributes to a more accurate identification of the potential hazard of waste to a human health, taking into account the greater number of factors and ways of the effect of toxic, radioactive and biologically hazardous components of the industrial waste on the human organism in comparison with techniques used in cancelled national standards.

Conclusions: The determination of the potential hazard category of mixtures of waste components by the assessment of inhalation acute toxicity $(R T)$ made it possible to determine the hazard class of waste not only by oral toxicity but taking into account the inhalation route of ingress into organism.

The assessment of the aggregate state of waste made it possible to determine the categories of risk and safety when handling them in terms of physical and chemical characteristics which made it possible to assess reasonably all possible manifestations of the potential hazard of waste for the environment and health of the population.

The realization of system approach to the determination of the potential hazard of the industrial waste, using standards (EU), is generally aimed to the improvement of regulated handling the waste and improvement of the state of the environment and health of the population.

Keywords: industrial waste, toxicity, hazard class, risk. сприяла більш чіткому визначенню загальної потенційної небезпеки відходів та шляхів поводження 3 ними. На основі цих основних положень було констатовано, що визначення потенційної небезпеки відходів має проводитися не лише за їхньою токсичністю, але й 3 обов'язковим урахуванням рівнів дій радіаційної компоненти та біологічних чинників антропогенного походження. Інтегральна оцінка ступеня небезпеки відходів при визначенні класу небезпеки проводилася за трьома блоками, поданими на рисунку.

Залежно від класу небезпеки за кожною складовою компонентою визначалася пріоритетність показників. При цьому більш безпечні за токсикологічними характеристиками відходи можуть бути віднесені до вищого рівня небезпеки за радіологічними або біологічними факторами, що вимагає застосування певних підходів до поводження з такими відходами. Такий комплексний підхід до встановлення класу небезпеки промислових відходів за показниками, які формують загальну санітарно-епідеміологічну загрозу цих утворень для навколишнього середовища та здоров'я людини, сприятиме чіткому ранжируванню відходів, впорядкуванню питань їх обліку та належного контролю над поводженням [3, 4].

Впровадження комплексної оцінки відходів вносило зміни до основного документа ДСанПіН 2.2.7.029-99, наразі скасованого, за методиками якого проводилися розрахунки складових відходів - хімічних речовин за параметрами їхньої гострої пероральної токсичності [5]. Але водночас не були враховані інші агрегатні стани відходів (пилова компонента, пара, гази, аерозолі) та основний інший шлях надходження до організму - інгаляційний. Крім того, недоліками ДСанПіН 2.2.7.029-99, за яким проводилися розрахунки визначення сумарного індексу токсичності (зазвичай за двома-трьома компонентами), що було покладено в основу встановлення класу небезпеки відходу, було й те, що не враховувались усі складові - хімічні речовини 3 високими або низькими значеннями концентрацій, внаслідок чого нівелювалася потенційна небезпека цих речовин і відходу загалом.

Такі положення щодо оцінки ступеня небезпеки хімічних

\section{Схема встановлення класу небезпеки відходів} вих відходів, визначені у відповідних Директивах Європейського Парламенту та Ради Європейських співтовариств «Про відходи» (75/442/ЄЕС від 15.07.1975, 2008/98/ЄС від 19.11.2008), «Про небезпечні відходи» (2006/12/€С від 05.04.2006, 91/689/ЄС від 12.12.1991) з подальшими змінами у Директивах Ради ЄС, якими встановлено принципові положення у сфері діяльності 3 відходами, що визначать подальші шляхи поводження 3 відходами на підприємствах та об'єктах, які $€$ джерелами їх утворення та здійснюють поводження з ними $[6,7]$.

Україною ратифіковано «Угоду про асоціацію 3 Європейським Союзом, 16.09.2014 і розроблено план імплементації, метою якого є забезпечення наближення законодавства України до законодавства ЄС у частині інтеграції екологічної політики та забезпечення мінімізації впливу негативних чин-

Рисунок

\begin{tabular}{|c|c|c|}
\hline \multicolumn{3}{|c|}{ ІНТЕГРАЛЬНА ОЦІНКА ВІДХОДУ } \\
\hline $\begin{array}{l}\text { ТОКСИКОЛОГІЧНА } \\
\text { КОМПОНЕНТА }\end{array}$ & $\begin{array}{c}\text { РАДІОЛОГІЧНА } \\
\text { КОМПОНЕНТА }\end{array}$ & $\begin{array}{c}\text { БІОЛОГІЧНА } \\
\text { КОМПОНЕНТА }\end{array}$ \\
\hline $\begin{array}{c}\text { Клас небезпеки } \\
\text { хімічної токсичності } \\
\text { (I, II, III, IV) дозово- } \\
\text { ефективна залежність }\end{array}$ & $\begin{array}{c}\text { Рівні дій } \\
\left(\mathrm{A}_{\text {еф }} \text { ПРН) }\right.\end{array}$ & $\begin{array}{c}\text { Якісні характеристики, } \\
\text { ступінь епідемічної } \\
\text { загрози }\end{array}$ \\
\hline
\end{tabular}


ників на здоров'я населення. На виконання завдань щодо реалізації плану імплементації $€$ розроблення проекту нормативно-правового акту на заміну ДСанПіН 2.2.7.029-99 «Гігієнічні вимоги щодо поводження 3 промисловими відходами та визначення класу їх небезпеки для здоров'я населення», що передбачає перехід на європейські норми визначення небезпечності відходів.

Мета роботи: обґрунтування впровадження сучасних підходів і методик за Директивами $€$ є для визначення потенційної небезпеки відходів.

Матеріали та методи дослідження. Матеріалами досліджень були результати санітарно-епідеміологічної оцінки промислових відходів 3 визначенням класу їх небезпеки за методиками скасованого ДСанПін 2.2.7.029-99 та Директивами ЄС і Регламенту ЄC 1272/2008 [8-10].

Нині в Україні не існує жодного нормативного документа, за яким може бути встановлено ступінь потенційної небезпеки відходів для довкілля і здоров'я населення. Фахівцями інституту розроблено проект документа ДСП «Встановлення класу небезпеки відходів». Керуючись положеннями відповідних Директив ЄС та Регламенту ЄC 1272/2008, ми визначили потенційну небезпеку різних видів промислових відходів за інгаляційного надходження до організму з урахуванням значень концентрацій усіх складових відходів та інших фізико-хімічних характеристик (агрегатний стан, значення $\mathrm{pH}$, вологість та інші властивості).

Результати дослідження та їх обговорення. Оцінку потенційної небезпеки рідких та твердих відходів, утворених у процесі виробничої діяльності підприємства ПрАТ «Кримський ТИТАН», проведено за результатами досліджень рідкого відходу із кислотонакопичувача та твердих відходів, відібраних із фосфогіпсосховища, з визначенням категорії небезпеки класу небезпеки за розрахунками (на підставі методики Регламенту ЄC № 1272/2008 CLP), в основу яких покладено результати визначення концентрацій кожного зі шкідливих компонентів суміші відходів важких металів та оцінка їхньої гострої токсичності (ГТ), яка для суміші визначається шляхом розрахунку виходячи 3 показників оцінки ГТ для кожного компонента, що враховується за формулою:

$$
\frac{100}{\mathrm{ATE}_{\text {mix }}}=\sum_{\mathrm{n}} \frac{\mathrm{C}_{\mathrm{i}}}{\mathrm{ATE}_{\mathrm{i}}} \text {, }
$$

де $\mathrm{C}_{\mathrm{i}}$ - концентрація (масова чи об'ємна частка, \%) компоненти i; i - номери компонент від 1 до n; n - кількість компонент; АТЕ - оцінка ГТ компоненти і.

$100-\left(\sum \mathrm{C}\right.$ невідомий, якщо $\left.\geq 10 \%\right)$

$$
\text { ATE }_{\text {mix }}
$$

3 урахуванням фізичного стану відходів (рідкі відходи із кислотонакопичувача у вигляді аерозолів, тверді відходи із фосфогіпсосховища у вигляді пилу) та складу компонентів відходів 3 вмістом важких металів проведено розрахунки визначення ступеня небезпеки - класу небезпеки відходів за інгаляційного шляху надходження до організму. Розрахунки за оцінкою ГТ з урахування параметрів гострої токсичності компонент відходу із кислотонакопичувача за інгаляцій-

ного надходження до організму подано у таблиці 1.

Результати розрахунків коефіцієнта визначення категорії небезпеки за співвідношенням сумарної концентрацій шкідливих речовин у складі промислових стоків із кислотонакопичувача та оцінки гострої токсичності кожної компоненти $\left(\mathrm{ATE}_{\mathrm{i}}\right)$ становить $\left(\Sigma \mathrm{C}_{\mathrm{i}} / \mathrm{ATE}_{\mathrm{i}}=\right.$ $0,154884 \% / 1,9469563=$ 0,0795518), що відповідно до шкали оцінки небезпеки $(0,05$ $<$ категорія $2 \leq 0,5)$ характерис зує рідину із кис$=\sum \stackrel{\mathrm{C}_{\mathrm{i}}}{\mathrm{ATE}}$ лотонакопичувача n ATE $_{\mathrm{i}}$ як відхід II класу небезпеки за інгаляційного надходження до організму у вигляді аерозолів.

Враховуючи значення параметрів гострої токсичності у разі орального надходження до організму хімічних речовин (ЛД $\left.{ }_{50}\right)$ у складі відходу із кислотонакопичувача (Pb, Cu, Cd, Zn, $\mathrm{Ni}, \mathrm{Ti}, \mathrm{As})$, проведено оцінку відходу з урахуванням визначених концентрацій у співвідношенні до оцінки гострої токсичності кожної компоненти $\left(\mathrm{ATE}_{\mathrm{i}}\right)$, за винятком цинку (Zn, титану (Ti) та арсену (As), вміст яких не визначався у деяких

Таблиця 1

\begin{tabular}{|l|c|c|c|c|c|c|c|}
\hline \multirow{2}{*}{$\begin{array}{c}\text { Назва дослід- } \\
\text { жуваного } \\
\text { об'єкта }\end{array}$} & \multicolumn{7}{|c|}{ Концентрація важких металів, \% } \\
\cline { 2 - 8 } & $\mathrm{Pb}$ & $\mathrm{Cu}$ & $\mathrm{Cd}$ & $\mathrm{Zn}$ & $\mathrm{Ni}$ & $\mathrm{Ti}$ & $\mathrm{As}$ \\
\hline $\begin{array}{l}\text { Відхід - ріди- } \\
\text { на із кислото- } \\
\text { накопичувача }\end{array}$ & 0,000124 & 0,0361 & 0,00013 & 0,0524 & 0,05332 & 0,01272 & 0,00009 \\
\hline $\begin{array}{l}\text { Клас токсич- } \\
\text { ності (повітря } \\
\text { робочої зони) }\end{array}$ & 1 & 2 & 2 & 1 & 1 & 3 & 2 \\
\hline AТЕ $_{\mathrm{i}}$ & 0,005 & 0,05 & 0,05 & 0,005 & 0,005 & 0,5 & 0,05 \\
\hline $\mathrm{C}_{\mathrm{i} / \mathrm{ATE}}$ & 0,0248 & 0,722 & 0,026 & 0,1048 & 1,0664 & 0,0011563 & 0,0018 \\
\hline
\end{tabular}

Таблиця 2

\section{Визначення ступеня небезпеки відходу із кислотонакопичувача за оцінкою ГТ за орального} шляху надходження до організму

\begin{tabular}{|l|c|c|c|c|c|c|c|}
\hline \multirow{2}{*}{$\begin{array}{c}\text { Назва } \\
\text { об'єкта }\end{array}$} & \multicolumn{6}{|c|}{ Концентрація важких металів, \% } \\
\cline { 2 - 8 } & $\mathrm{Pb}$ & $\mathrm{Cu}$ & $\mathrm{Cd}$ & $\mathrm{Zn}$ & $\mathrm{Ni}$ & $\mathrm{Ti}$ & $\mathrm{As}$ \\
\hline $\begin{array}{l}\text { Відхід - } \\
\text { рідина із } \\
\text { кислотона- } \\
\text { копичувача }\end{array}$ & 0,000124 & 0,0361 & 0,00013 & - & 0,05332 & - & 0,00009 \\
\hline АТЕ $_{\mathrm{i}}$ & 100 & 100 & 100 & - & 100 & 500 & 100 \\
\hline $\mathrm{C}_{\mathrm{i}} /$ АТЕ $_{\mathrm{i}}$ & 0,00000124 & 0,000361 & 0,0000013 & - & 0,0005332 & - & 0,0000009 \\
\hline
\end{tabular}


пробах (ЛД $50>2000$ мг/Кг). Визначення ступеня небезпеки відходу із кислотонакопичувача за оцінкою ГТ за орального надходження до організму подано у таблиці 2.

Результати розрахунків для визначення категорії небезпеки рідкого промислового відходу із кислотонакопичувача за оцінкою гострої токсичності за орального шляху надходження до організму визначилися на рівні $\left(\sum \mathrm{C}_{\mathrm{i}} / \sum \mathrm{ATE}_{\mathrm{i}}\right)=0,089683 /$ $0,00089764=99,90976)$, що за шкалою категорії небезпеки (50<категорія $3 \leq 300)$ характеризує відхід як помірно небезпечний - III клас.

Оцінка ступеня небезпеки твердого промислового відходу із фосфогіпсосховища проводилася на основі розрахунків індексів токсичності для кожного $з$ хімічних елементів для встановлення відповідного класу небезпеки за методиками ДСанПіН 2.2.7.029-99 щодо визначення індексів токсичності, розрахованими за параметрами токсичності за орального надходження до організму хімічних елементів (важких металів) у суміші відходу, а також для порівняння на основі сучасних підходів, зазначених у методиках розрахунків за Регламентом ЄC 1272/2008. Результати розрахунків індексів токсичності хімічних елементів у дослідженому відході подано у таблиці 3.

За отриманими результатами досліджень відходу із відвалу фосфогіпсосховища з урахуванням значень індексів токсичності важких металів сумарний індекс токсичності було визначено на рівні $K \sum 18,3>10$, що відповідно до шкали класифікації ступеня небезпеки за ДСанПіН 2.2.7.029-99 характеризує відхід із відвалу фосфогіпсосховища як малонебезпечний - IV клас небезпеки. Визначення категорії небезпеки - класу небезпеки відходу із відвалу фосфогіпсосховища проведено за оцінкою ГТ за орального шляху надходження до організму за методиками Регламенту ЄC 1272/2008 подано у таблиці 4.

Результати розрахунків коефіцієнтів (табл. 4), за якими визначалася категорія небезпеки відходу із відвалу фосфогіпсосховища за оцінкою ГТ за орального шляху надходження до організму, показали, що коефіцієнт відношення сумарної концентрації шкідливих речовин у складі відходу становить $\left(\sum \mathrm{C}_{\mathrm{i}} / \sum \mathrm{ATE}_{\mathrm{i}}=0,005798 \%\right.$ / $0,00005798=100)$, що за шкалою оцінки категорії небезпеки (50< категорія $3 \leq 300)$ характеризує його як помірно небезпечний - III клас небезпеки за орального шляху надходження до організму. Таким чином, за розрахунками відповідно до методик Регламенту ЄС 1272/2008 відхід із відвалу фосфогіпсосховища за параметрами гострої оральної токсичності класифіковано як помірно небезпечний - III клас, а за методиками розрахунків ДСанПіН 2.2.7.029-99 відхід класифіковано як малонебезпечний - IV клас. Порівняння отриманих результатів свідчить про перевагу застосування сучасних підходів і методик для встановлення потенційної небезпеки відходів.

Зважаючи на те, що досліджений відхід за агрегатним станом є твердою субстанцією, який перебуває на відкритому просторі і за певних умов здат-

\section{у пробі відходу із відвалу фосфогіпсосховища}

\begin{tabular}{|c|c|c|c|c|}
\hline $\begin{array}{c}\text { Назва } \\
\text { хімічного } \\
\text { елемента }\end{array}$ & $\begin{array}{c}\text { Концентрація, } \\
\text { мг/кг }\left(\mathrm{C}_{\text {факт })}\right.\end{array}$ & $\begin{array}{c}\text { Концентрація, } \\
\text { кг/т } \\
\left(\mathrm{C}_{\text {факт }}\right)\end{array}$ & Lg лд & $\begin{array}{c}\text { Індекс } \\
\text { токсичності } \\
\left(\mathrm{K}_{\mathrm{i}}\right)\end{array}$ \\
\hline $\mathrm{5}$ & \multicolumn{5}{|c|}{ Проба відходу із відвалу фосфогіпсосховища } \\
\hline $\mathrm{Pb}$ & 1,2 & 0,0012 & 1,8692 & 1557,7 \\
\hline $\mathrm{Cd}$ & 4,8 & 0,0048 & 2,0345 & 423,85 \\
\hline $\mathrm{Zn}$ & 26,0 & - & & - \\
\hline $\mathrm{Ni}$ & 48,98 & 0,04898 & 2,066 & 42,18 \\
\hline $\mathrm{Ti}$ & 121,54 & 0,12154 & 3,778 & 31,08 \\
\hline $\mathrm{As}$ & 3,0 & 0,003 & 2,079 & 693 \\
\hline
\end{tabular}

Таблиця 4

Визначення ступеня небезпеки відходу із відвалу фосфогіпсосховища за оцінкою ГТ за орального шляху надходження до організму

\begin{tabular}{|l|c|c|c|c|c|}
\hline \multirow{2}{*}{ Назва об'єкта } & \multicolumn{5}{|c|}{ Концентрація важких металів, \% } \\
\cline { 2 - 6 } & $\mathrm{Pb}$ & $\mathrm{Cu}$ & $\mathrm{Cd}$ & $\mathrm{Ni}$ & $\mathrm{As}$ \\
\hline $\begin{array}{l}\text { Проба відходу } \\
\text { із відвалу } \\
\text { фосфогіпсосховища }\end{array}$ & 0,00012 & 0,00048 & - & 0,004898 & 0,0003 \\
\hline $\begin{array}{l}\text { АТЕ } \\
\text { токси параметрами }\end{array}$ & 100 & 100 & 100 & 100 & 100 \\
\hline $\begin{array}{l}\text { С }_{\mathrm{i}} / \mathrm{ATE}_{\mathrm{i}} \\
\text { (проба з відвалу) }\end{array}$ & 0,0000012 & 0,0000048 & - & 0,00004898 & 0,000003 \\
\hline
\end{tabular}


шення сумарної концентрації шкідливих речовин у складі відходу становить $\left(\sum \mathrm{C}_{\mathrm{i}} / \sum \mathrm{ATE}_{\mathrm{i}}=\right.$ $0,020552 \% / 0,1438649=$ $0,14285625)$, що за шкалою оцінки категорії небезпеки $(0,05$ $<$ категорія $2 \leq 0,5)$ характеризує відходи із відвалу фосфогіпсосховища як відходи II класу небезпеки за інгаляційного надходження до організму.

Цей приклад є наочним свідченням того, що зважаючи на сучасні підходи у визначенні класу небезпеки розрахунки за методиками нормативних документів ЄС проводяться більш обґрунтовано, з урахуванням усіх визначених компонент, а не тільки тих, які мають найменші значення індексів токсичності. За оцінкою інгаляційної ГТ компонент відходів визначено категорії їхньої потенційної небезпеки у разі надходження до організму не лише оральним, але й інгаляційним шляхом.

Всебічна оцінка небезпеки відходів була би недостатньою без урахування ризиків, які зумовлені фізичним станом сумішей хімічних речовин у складі відходів. Згідно 3 Директивою ЄС № 2001/59 усі хімічні речовини класифікуються за ризиком (R) і безпекою (S) 3 переліком кодів (букваномер) конкретних факторів ризику або вказівок з безпеки. Букви-номери R1-R68 вказують перелік ризиків, пов'язаних $з$ речовинами або їхніми сумішами, які можуть характеризувати окремі властивості речовини та у різних сполученнях. Наприклад, R1-R19 характеризують переважно фізикохімічні властивості речовин або сумішей, такі як вибухонебезпечне у сухому вигляді, вибухонебезпечне при контакті 3

Визначення ступеня небезпеки відходу із відвалу фософогіпсосховища за оцінкою ГТ з урахуванням параметрів гострої токсичності компонент за інгаляційного надходження до організму

\begin{tabular}{|l|c|c|c|c|c|c|c|}
\hline \multirow{2}{*}{$\begin{array}{l}\text { Назва досліджу- } \\
\text { ваного об'єкта }\end{array}$} & $\mathrm{Pb}$ & $\mathrm{Cu}$ & $\mathrm{Cd}$ & $\mathrm{Zn}$ & $\mathrm{Ni}$ & $\mathrm{Ti}$ & $\mathrm{As}$ \\
\cline { 2 - 8 } \\
\hline $\begin{array}{l}\text { Відхід із відвалу } \\
\text { фосфогіпсо- } \\
\text { сховища }\end{array}$ & 0,00012 & 0,00048 & - & 0,0026 & 0,004898 & 0,012154 & 0,0003 \\
\hline $\begin{array}{l}\text { Клас токсично- } \\
\text { сті (повітря } \\
\text { робочої зони) }\end{array}$ & 1 & 2 & 2 & 1 & 1 & 3 & 2 \\
\hline АТЕ & 0,005 & 0,05 & 0,05 & 0,005 & 0,005 & 0,5 & 0,05 \\
\hline $\begin{array}{l}\text { С }_{\mathrm{i}} / \text { АТЕ } \\
\text { із (проба }\end{array}$ & 0,024 & 0.0096 & - & 0,0052 & 0.09796 & 0,0011049 & 0,006 \\
\hline
\end{tabular}

токсикологічними характеристиками хімічних речовин у складі відходу він може характеризуватись як малонебезпечний і належати до IV класу, але, наприклад, червоний шлам, що утворюється на глиноземному виробництві, має значення $\mathrm{pH}>12,0$ і за фізичним станом «надзвичайно високий ступінь дисперсності пилу», що проявляється різким подразненням слизових оболонок очей і верхніх дихальних шляхів і потребує щільних засобів їх захисту, а рідкі відходи із кислотонакопичувача зі значенням рH = 0,00-0,58 свідчать про надзвичайно високий рівень накопичення різних кислот у його складі. Враховуючи екстремальні значення $\mathrm{pH}>12,0, \mathrm{pH}=$ 0,00-0,58 та зважаючи на їх відкрите зберігання у шламонакопичувачі та кислотонакопичувачі, бачимо, що клас небезпеки, встановлений за параметрами гострої токсичності за орального шляху надходження, не повністю відображає ступінь небезпеки таких відходів.

Саме застосування підходу до визначення класу небезпеки з урахуванням фізико-хімічних властивостей відходів за методиками розрахунків у відповідності до вимог Директив та Регламенту ЄC 1272/2008 за інгаляційного та дермального шляхів надходження до організму суттєво збільшує можливості для встановлення з більшою точністю категорії небезпеки таких відходів. Ознаки ризиків для червоного шламу позначаються символами ризиків: R20 - небезпечне при вдиханні, R21 - небезпечне при контакті зі шкірою, R36, R41 - викликає подразнення очей, ризик серйозного ушкодження очей, R48 небезпека серйозного ушкодження здоров'я за довготривалої дії, R65 - небезпечне, бо може заподіяти шкоду легеням. Рідкий відхід із кислотонакопичувача $\mathrm{pH}=0,00-0,58$ позначається тими саме символами ризиків. Крім того, такий відхід потребує особливих умов щодо захисту довкілля і населення, позначається символом S57 - попередження забруднення навколишнього середовища.

Дослідження умов поводження 3 відходами одорантів 
природного газу (етил-, метилмеркаптанами) показали, що ці речовини та продукти їх розкладання (пропіл-, ізопропіл-, ізобутилмеркаптани та інші) присутні у повітрі у вигляді пари, яка накопичується у низинних місцях, підвалах, на робочих місцях 3 недостатньої вентиляцією і герметичністю обладнання. Після контакту з ними ризики небезпеки для здоров'я можуть бути незворотними. Такі відходи, як масла технічні індустріальні за ступенем небезпеки можуть класифікуватись як відходи III-IV класу, але при контактах з незахищеною шкірою викликають різні ступені подразнення, утворення виразок, деструктивні зміни на шкірі, ураження кісток. Зазначені ризики також мають бути врахованими і позначеними для відходу при визначенні ступеня його небезпеки.

\section{Висновки}

1. Встановлено, що застосування сучасних підходів до оцінки небезпеки відходів 3 урахуванням нормативних документів $€ С$ дозволило суттєво удосконалити методику встановлення класу небезпеки промислових відходів та точніше визначити їхню потенційну небезпеку для довкілля і здоров'я населення з урахуванням більшої кількості чинників негативної дії та потенційних шляхів їх надходження до організму людини.

2. Урахування інгаляційного шляху надходження до організму сумішей складових відходів дозволяє за оцінкою інгаляційної гострої токсичності (ГТ) складу відходів визначити категорії їхньої потенційної небезпеки у разі надходження до організму не тільки оральним, але й інгаляційним шляхом.

3. Агрегатний стан відходів дозволяє за фізико-хімічними властивостями визначити категорії ризиків і безпечності при поводженні, що дозволяє обґрунтовано оцінити усі можливості їхньої потенційної небезпеки для довкілля і здоров'я населення.

4. Впровадження системного підходу до визначення потенційної небезпеки промислових відходів з застосуванням методик нормативних документів Європейського Союзу спрямоване на удосконалення системи урегульованого поводжен- ня з відходами, що сприятиме поліпшенню стану навколишнього середовища і здоров'я населення.

ЛІТЕРАТУРА

1. Гігієнічні вимоги щодо поводження з промисловими відходами та визначення їх класу небезпеки для здоров'я населення : ДСанПіН 2.2.7.029-99 / МОЗ України. К., 1999. $40 \mathrm{c}$

2. Станкевич В.В.,

Какура І.В., Костенко А.І. Пріоритетність визначення індексів токсичності за параметрами токсикометрії при встановленні класу небезпеки промислових відходів. Київ, 2010 (Інформаційний лист про нововведення у системі охорони здоров'я /

Укрмедпатентінформ, № 352009).

3. Станкевич В.В.,

Какура І.В., Костенко А.І. Супутні фактори потенційної небезпеки промислових відходів. Київ, 2009. (Інформаційний лист про нововведення у системі охорони здоров'я / Укрмедпатентінформ, № 1822010).

4. Станкевич В.В.,

Какура I.В., Костенко А.І. Комплексний підхід до визначення класів небезпеки промислових відходів. Київ, 2010. (Інформаційний лист про нововведення у системі охорони здоров'я / Укрмедпатентінформ, № 183-2010).

5. Станкевич В.В., Костенко A.І., Какура І.В. та ін. Обґрунтування внесення змін до ДСанПіН 2.2.7.029-99. Розділ 5. Визначення класу небезпеки промислових відходів. Актуальні питання гігієни та екологічної безпеки України (XI марзєєвські читання) : зб. тез доп. наук.-практ. конф. К., 2015. Вип. 15. C. 62-64.

6. Директива № 91/689/EC Совета Европейских

Сообществ «Об опасных отходах». URL : http://zakon5.

rada.gov.ua/laws/show/994_89.

7. Директива Європейського Парламенту та Ради 2008/98/ЄС «Про відходи та скасування деяких Директив» від 19.11.2008. URL

http://base.consultant.ru/cons/ cgi/online. cgi?req=doc; base $=$ INT: $n=46745$.

8. Регламент $\in C$

№ 1272/2008 Європейського
Парламенту та Ради від 16.12.2008 (Про класифікацію, маркування та пакування речовин та сумішей, що вносить зміни та скасовує Директиви 67/548/ЄEC і 1999/45/ЄС та вносить зміни до Регламенту ЄC

№ 1907/2006/.

9. Трахтенгерц Г.Я. Вплив накопичувачів відходів гірничозбагачувального комплексу України на довкілля. Довкілля та здоров'я. 2015. № 2 (73). С. 58-61.

10. Станкевич В.В., Костенко А.І., Трахтенгерц Г.Я.

Впровадження гармонізованих стандартів у сфері поводження з відходами. Актуальні питання гігієни та екологічної безпеки України (XII марзєєвські читання) : зб. тез доп. наук.практ. конф. К., 2016. Вип. 16. C. 192-195.

\section{REFERENCES}

1. Hihienichni vymohy shchodo povodzhennia z promyslovymy vidkhodamy ta vyznachennia yikh klasu nebezpeky dlia zdorovia naselennia [Hygienic Requirements to Handling the Industrial Waste and Determination of their Hazard Classes for the Health of the Population] : DSanPiN

2.2.7.029-99. Kyiv ; 1999 : 40 p. (in Ukrainian).

2. Stankevych V.V., Kakura I.V. and Kostenko A.I. Priorytetnist vyznachennia indeksiv toksychnosti za parametramy toksykometrii pry vstanovlenni klasu nebezpeky promyslovykh vidkhodiv : Informatsiinyi lyst pro novovvedennia $v$ systemi okhorony zdorovia № 35-2009 [Priority of the Determination of Toxicity Indices by the Parameters of Toxicometry at the Determination of Hazard Class of the Industrial Waste: Information Letter on the Innovation in Health Care System № 35-2009]. Kyiv ; 2010. (in Ukrainian).

3. Stankevych V.V., Kakura I.V. and Kostenko A.I. Suputni factory potentsiinoi nebezpeky promyslovykh vidkhodiv : Informatsiinyi lyst pro novovvedennia $v$ systemi okhorony zdorovia № 182-2010 [Attendant Factors of the Potential Hazard of the Industrial Waste: Information Letter on the Innovation in Health Care System № 182-2010]. Kyiv ; 2009. (in Ukrainian). 
4. Stankevych V.V., Kakura I.V. and Kostenko A.I. Kompleksnyi pidkhis do vyznachennia klasiv nebezpeky promyslovykh vidkhodiv: Informatsiinyi lyst pro novowedennia v systemi okhorony zdorovia № 183-2010 [Complex Approach to the Determination of Hazard Classes of the Industrial Waste: Information Letter on the Innovation in Health Care System № 183-2010]. Kyiv ; 2010. (in Ukrainian).

5. Stankevych V.V., Kostenko A.I., Kakura I.V. et al. Obhruntuvannia vnesennia zmin do DSanPin 2.2.7.029-99.

Rozdil 5. Vyznachenniz klasu promyslovykh vidkhodiv [Substantiation of Changes in the State Sanitary Rules and Norms 2.2.7.029-99. Chapter 5. Determination of Hazard Classes of the Industrial Waste]. In : Aktualni pytannia hihiieny ta ekolohichnoi bezpeky Ukrainy : tezy konf. [Actual Issues of Hygiene and Ecological Safety of Ukraine: Conf. Theses] Kyiv ; 2015 ; 15 : 62-64 (in Ukrainian).

6. Council Directive № 91/689/EEC of 12 December 1991 on Hazardous Waste. Official Journal L 377.

31/12/1991. P. 0020-0027.

7. Directive $2008 / 98 / E C$ of the EUROPEAN PARLIAMENT and of the COUNCIL of 19.11.2008 on Waste and Repealing Certain Directives.

8. REGULATION (EC) № 1272/2008 OF THE EUROPEAN PARLIAMENT AND OF THE COUNCIL of 16.12.2008 on Classification, Labelling and Packaging of Substances and Mixtures, Amending and Repealing Directives 67/548/EEC and 1999/45/EC, and Amending Regulation (EC) № $1907 / 2006$.

9. Trakhtenherz H.Ya. Dovkillia ta zdorovia. 2015; 2 (73) : 5861(in Ukrainian).

10. Stankevych V.V., Kostenko A.I. and Trakhtenherz H.Ya. Vprovadzhennia harmonizovanykh standartiv u sferi povodzhennia z vidkhodamy [Implementation of Harmonized Standards in the Sphere of Handling the Waste]. In Aktualni pytannia hihiieny ta ekolohichnoi bezpeky Ukrainy : tezy konf. [Actual Issues of Hygiene and Ecological Safety of Ukraine : Conf. Theses]. Kyiv ; $2016 ; 16: 192-195$ (in Ukrainian).

Надійшло до редакції 02.06.2018
ESTIMATION OF THE RADON CONCENTRATIONS IN CHILDREN'S EDUCATIONAL INSTITUTIONS OF KROPYVNYTSKVI CITY FOR RADON PROTECTIVE ACTIONS

Fryziuk M.A., Aksionov N.V., Fedorenko O.V., Slinchenko V.A., Chuchupal I.I.

ОЦПКА РІВНВВ РАДОНУ У ДИТЯЧИХ НАВЧАЛЬНИХ ЗАКЛАДАХ М. КРОПИВНИЦЬКИЙ ДЛЯ ВПРОВАДЖЕННЯ ПРОТИРАДОНОВИХ ЗАКОДВ
1ФРИЗЮК М.А. 1 АКСЬОНОВ М.B, 1ФЕДОРЕНКО О.В, 2СЛІНЧЕНКО В.А. 2ЧУЧУПАЛ І.І.

1 ДУ «Інститут громадського здоров'я ім. О.М. Марзєєва НАМН України», м. Київ, Україна

2Управління з питань цивільного захисту

Кіровоградської обласної дежавної адміністрації,

м. Кропивницький, Україна

УДК 614.876:613.55:546.296

Ключові слова: радон

у повітрі приміщень,

протирадонові заходи. радіологічної точки зору природний радіоактивний газ радон є домінуючим джерелом опромінення населення. Його внесок у сумарну дозу опромінення становить понад 50\%. У багатьох значущістю причиною раку легенів після куріння. Крім того, він $€$ основною причиною раку легенів в осіб, які ніколи не палили $[1,2]$

Біологічна дія радону на організм людини виражається у тому, що альфа-випромінювання 3 великою енергією, яке супроводжує розпад, може країнах радон $€$ другою за

ОЦЕНКА УРОВНЕЙ РАДОНА В ДЕТСКИХ УЧЕБНЫХ ЗАВЕДЕНИЯХ Г. КРОПИВНИЦКИЙ ДЛЯ ПРОВЕДЕНИЯ ПРОТИВОРАДОНОВЫХ МЕРОПРИЯТИЙ Фризюк М.А., Аксенов Н.В., Федоренко Е.В., Слинченко В.А., Чучупал И.И. ГУ «Институт общественного здоровья им. А.Н. Марзеева НАМН Украины», Г. Киев

Цель работы. Исследование уровней радона в воздухе помещений дошкольных и школьных заведений г. Кропивницкий Кировоградской области для проведения в дальнейшем эффективных противорадоновых мероприятий.

Материалы и методы. Исследования включали измерения эквивалентной равновесной объемной активности (ЭРОА) радона-222 в воздухе помещений детских учебных заведений. Измерения проводились в отопительный сезон методом пассивной трековой радонометрии с использованием в качестве детектора нитрат-целлюлозной пленки LR115. Время экспонирования радоновых накопителей составляло не менее 30 суток. Химическая обработка детекторов выполнялась в растворе щелочи $\mathrm{NaOH}(2,5 \mathrm{M})$. Подсчет треков осуществлялся с помощью искрового счетчика АИСТ.

Результаты. Исследования проводились в воздухе помещений дошкольных и школьных заведений г. Кропивницкий. Установлено, что диапазон значений ЭРОА радона-222 составлял от 12 Бк м $^{-3}$ до 332 Бк $M^{-3}$, среднее арифметическое значение - $85 Б^{\circ} \cdot M^{-3}$, среднее геометрическое - 69 Бк $\cdot \mathrm{M}^{-3}$ при стандартном отклонении $595 \mathrm{~L}^{\cdot} \mathrm{M}^{-3}$. Уровни радона-222 превышали гигиенический норматив для детских заведений (50 Бк $\mathrm{M}^{-3}$ ) в $64 \%$ обследованных помещений, из них в 8 помещениях превышение норматива составило 4-6 раз. ЭРОА радона-222 в помещениях, расположенных на первом этаже, почти в 2 раза больше, чем в помещениях, находящихся выше первого этажа. Во всех зданиях, где зафиксированы уровни радона в воздухе помещений, превышающие гигиенический норматив, необходимо провести противорадоновые мероприятия. Оптимальные защитные меры определяются отдельно для каждого конкретного помещения или здания и основываются на анализе и качественной оценке конструктивных характеристик здания и путей поступления радона в него. Эффективность проведенных защитных мероприятий устанавливается по результатам повторных измерений уровней радона в тех же помещениях.

Ключевые слова: радон в воздухе помещений, противорадоновые мероприятия.

(C) Фризюк М.А., Аксьонов М.В, Федоренко О.В, Слінченко В.А., Чучупал I.I. СТАТTЯ, 2018. 